\title{
Managing Reputation, Sustainability, and Self-Interest: The Case of CEO Remuneration in the United States and the Importance of Being Earnest
}

\author{
Ernest H. Hall Jr. \& Jooh Lee ${ }^{2}$ \\ ${ }^{1}$ Romain College of Business, University of Southern Indiana, Evansville, Indiana, United States of America \\ ${ }^{2}$ Rohrer College of Business, Rowan University, Glassboro, New Jersey, United States of America \\ Correspondence: Ernest H. Hall Jr., Romain College of Business, University of Southern Indiana, Evansville, \\ Indiana, 47712, United States of America.
}

Received: August 2, 2021

doi:10.5539/ibr.v14n10p57
Accepted: August 31, 2021

Online Published: September 8, 2021

URL: https://doi.org/10.5539/ibr.v14n10p57

\begin{abstract}
Executive compensation has long been a lightening-rod of interest in the popular press and frequently makes the headlines. It seems that everyone has an opinion on the subject, with most demanding an end to inflated compensation packages. Depending on whether you are a member of the C-suite or not will likely skew your opinion on the matter. Given that the CEO is the most visible manifestation of the company to the outside world it is common to fixate on the way in which they are being compensated. However, after all of the research that has been conducted, we are still not sure about what factors determine a business executives' pay. The present study seeks to add to the extant literature on the subject of CEO compensation by introducing a couple of promising new variables: corporate reputation and sustainability. It is argued that since the CEO is the face of the organization that he/she will be compensated based on how well they manage the firm's reputation overall and its "environmental footprint" in particular.
\end{abstract}

Keywords: reputation, sustainability, remuneration

\section{Introduction}

In a play on words from the classic English play by Oscar Wilde, The importance of Being Earnest, the question of whether it pays to be green and sustainable is an important one. The salient point of this reference is: Are CEOs, as the face of the company, being 'earnest' in their commitment to sustainability? Or, are they merely playing the part of Ernest, as the alter ego of Jack Worthing in Ocar Wilde's play "The Importance Of Being Earnest"? So, what is the relationship between a firm's actions when it comes to sustainability and CEO remuneration? Are CEOs being duly compensated for their sustainability efforts?

\section{Executive Remuneration}

One of the most widely debated topics in the business literature is executive compensation or to be more specific, the commonly criticized excessive compensation packages being paid to corporate executives. In an effort to help explain the variation in CEO compensation across businesses the present study will investigate the impact of corporate reputation and sustainability on remuneration (Hall \& Lee, 2011; Lee \& Hall, 2008). In particular, we will seek to assess the impact of a firm's overall reputation and its position on "sustainability" on CEO compensation. To do this we will make use of three different measures of CEO compensation, namely; salary and bonus, long-term compensation, and total compensation. These three measures of remuneration the most widely utilized measures of executive remuneration in the extant literature.

It has been argued that a firm's reputation is a very valuable strategic asset (Barney, 1991; Porter, 1990) when it comes to determining a firm's performance, with several studies finding a positive relationship between reputation and financial performance (Hall, Lee, \& Whang, 2011; Lee \& Hall, 2008). In spite of such findings, Fryxell \& Wang (1994) still contend that commonly used measures or proxies of reputation are based on a financial 'halo' effect that explains these results (to be specific, the Fortune reputation index). The impact of such a financial halo effect will revisited at a later point in time. A subsequent study by Hall \& Lee (2011) found evidence to support a strong relationship between a firm's reputation and performance, even after removing the 
financial halo proposed by Fryxell \& Wang (1994).

So, how much is a good corporate reputation worth? Although the issue has been widely debated, the causal relationship of whether a good reputation leads to superior firm performance or superior firm performance leads to a better reputation has not been conclusively studied at the present time. A case can easily be made that a favorable corporate reputation may offer an organization opportunities not available to firm's with less favorable reputations, such as charging higher prices (Klein \& Leffler, 1981; Milgrom \& Roberts, 1986), influencing buyer preferences and buying behavior (Dowling, 1986), inhibiting inter-industry rivalry among competitors (Caves \& Porter, 1977; Wilson, 1985), and possibly improving a firm's social status in its industry (Shrum \& Wuthnow, 1988).

On the other hand, it can be argued from a totally opposite perspective, where firms would likely receive financial remuneration for behaving in a socially responsible manner. Such socially responsible behaviors would resonate with key firm stakeholders, which would in turn increase the firm's overall value and reputation. The exact reason for such a relationship is not the subject of the present paper and therefore will not be addressed in any detail. However, what is important to the present study is: 1) The consistently positive correlation between a firm's reputation and its organization performance, and 2) Extending the performance-reputation linkage to newly developed sustainability measures.

\section{Sustainability}

The subject of sustainability has continued to gain traction over the recent past and by all expectations, looks likely to continue to garner an ever-increasing portion of the buying public's attention (Heineman, 2016; Kiron, Kruschwitz, Haanaes, \& Von Streng Velken, 2009; Kochan, 2015; Suriyankietkaew \& Petison, 2020). Although very few things are certain in this world of change, one thing seems certain: being green and sustainable has become a strategic imperative within the business world. No longer can business executives ignore the social mores of their customers (Kochan, 2015). It has become a growing trend that consumers' buying behaviors are increasingly becoming a matter of the heart and that an individual's social compass will increasingly play a larger role in buying decisions in the future (Heineman, 2016).

In order to respond, nay, in order to embrace this new social condition (Kiron, Kruschwitz, Haanaes, \& Von Streng Velken, 2009; Suriyankietkaew \& Petison, 2020), executives need to take a more active role in utilizing and exploiting this new consumer behavior. As business executives continue to adapt and evolve in response to this new business paradigm, they will be mandated to incorporate and develop new skills for succeeding in what is sure to be a transparent society Future CEOs and business leaders will be mandated to develop skills and an aptitude for managing in what is surely to be an increasingly transparent society (Heineman, 2016; Kochan, 2015). One of the quickest and most surefire strategies for convincing executives that 'going green' is in their best interest is to align their compensation with 'green and sustainable' corporate goals. To this end, the present study will investigate the impact of two factors, sustainability and corporate reputation, and their impacts on CEO remuneration.

Carbon footprints, environmental impact, and recycling, are just a few of the many words and phrases that have become commonplace in the boardroom over the recent past. It is expected that such ethical and environmental issues will continue to demand more and more of the attention of senior management. As customers are starting to vote with their hearts, as well as their feet, there will be an increasing amount of pressure exerted on businesses to minimize or eliminate their negative effects on the environment (Kiron, Kruschwitz, Haanaes, \&Von Streng Velken, 2009; Suriyankietkaew \& Petison, 2020). Corporate sustainability has become a very popular topic of late and is can be easily defined as the desire to "meet present needs without compromising the ability of future generations to meet their needs"(WECD, 1987).

Therefore, the concept of sustainability has taken on an "ethical" flavor and is frequently associated with how a firm's is viewed when it comes to the use and disposal of raw materials (Heineman, 2016). The phrase "cradle to grave" has been modified to "cradle to cradle" to reflect how firms are expected to manage their resources in a more responsible fashion. The idea is that raw materials are to be used in such a way that that the waste and end products of a firm will become the feed stocks for new products, thereby, limiting pollution and maximizing the usefulness of all raw materials. Firms that adopt a more efficient view of the uses of raw materials are considered to be more ecologically friendly or "green."

In a special issue of the Sloan Management Review, Editor-in-Chief, Michael Hopkins (2009a) suggested a different perspective when it comes to the impact of sustainability on business, suggesting that:

Even as attention is increasingly paid to "going green" and to the role business can play to help solve 
sustainability problems, the flip side of the business-and-sustainability relationship has gone underexamined. Forget how management can affect sustainability. How will sustainability change management? (p.19)

This "greening" of the business environment mandates that firms be cognizant and aware of stakeholder theory and the influence of various constituencies. It is critical that managers understand the relationship between the company and the impact that different stakeholders can have on the operations of a business and in the end, its profitability. Given the speed and momentum that the sustainability movement has been able to muster over the last decade, it is critical that managers not ignore such an influential shift in business practice. Ignoring such a wide-ranging force could negatively affect a firm in the market and financial community. On the other hand, instead of viewing the sustainability movement as a negative force that must be accommodated or tolerated, it may be a more productive use of a firm's energy to frame sustainability as an opportunity to develop a competitive advantage (Heineman, 2016; Hopkins, 2009b). Taking a more proactive stance on sustainability may give a firm a leadership role in environmental issues. Such a leadership position has the potential to pay dividends in superior profitability and reputation.

It is important for businesses to remember a simple and very basic business principle: customers vote by deciding where to spend their money, and will seek out firms that embrace their values. Buying decisions are increasingly becoming not just a matter of dollars and cents, but matters of the heart. Such heartfelt values, like sustainability and environmentalism, will play a larger role in purchasing decisions in the future. Customers are more likely to patronize firms that share their views on ethical and moral issues, or at least that is the argument put forth by social legitimacy.

One does not have to look far for examples of the impact that negative publicity can play on a firms' operations. Apple, always viewed as a socially responsible firm, has suffered due to human resource issues enforced by their suppliers in China (Foxconn). In response to these lapses in moral and ethical standards, Apple has been forced to undertake a thorough audit of its international suppliers and make wide-ranging changes. It is no longer acceptable for firms to outsource their manufacturing to the cheapest provider without considering the social and ethical implications of using certain supplies and suppliers. Current customers will no longer tolerate or condone business practices that fail to maintain high moral standards. Customers are increasingly voting and buying with their conscience and not merely based on price. If firms expect a customers' patronage it will have to meet their social and moral standards. On a related note, it is important to recognize that firms must also meet the social and ethical standards demanded by future employees. No longer are employees merely interested in just a pay check.

Firms are not only being held responsible for their own actions, but for the actions of their suppliers and outsourced partners. The interesting part of these relationships is that the firm does not own their suppliers or outsourced partners. However, such a distinction is not relevant in the customers' eyes. Crossing international borders to outsource assembly or purchase component parts is being held to the same standard as if the firm manufactured the supplies themselves. For example, Apple and Nike were both held accountable by their customers for outsourced parts and assembly to foreign countries. One company, Sam's Club, has even taken things a step further, by introducing its own line of jewelry known as "Love, Earth." Love, Earth is a new product line that seeks to satisfy the exacting standards adopted by the more socially conscious customer. Lying at the heart of "Love, Earth" is that Sam's Club certifies all of the raw materials (in this case diamonds and gold) has been obtained from legitimate suppliers (see the movie "Blood Diamonds").

In light of this more demanding and socially conscious customer many businesses are taking a more active role in vetting their suppliers. In fact, companies are requiring their suppliers to develop sustainability programs to mimic the socially responsible actions of the company. If a supplier fails to uphold the sustainability standards set by the company they risk being decertified, and therefore will lose the company's business. Such proactive actions reflect how serious the sustainability movement has become. All indicators suggest that the sustainability movement will continue to gain momentum and legitimacy in the future (Heineman, 2016). Firms that choose to ignore or discount the strength of the sustainability movement will likely pay a price in the market and financial arenas. As the customer becomes more socially conscious and increasingly active, firms will have to respond in new, socially legitimate ways or suffer the consequences or a changing world of business.

\section{Corporate Reputation}

One of the many definitions of corporate reputation that has gained popularity in the business world suggests that a firm's reputation is a composite measure of a plethora of factors that results in an aggregate assessment of a firm's future societal impact and economic potential by external constituents, such as society at large, customers, 
suppliers, etc. Barney (1991) argues that corporate reputation may serve as a competitive advantage that can be sustainable over long periods of time. An alternate definition of corporate reputation argues that it is "a perceptual representation of a company's past actions and future prospects that describe the firm's overall appeal to all its key constituents when compared to other leading rivals." (Fombrun, 1996: 72) No matter which definition or approach is adopted or how it is operationalized, it can clearly be concluded that a firm's reputation is a valuable asset that cannot be ignored. Developing, maintaining, enhancing, and managing a company's reputation are critical functions that demand the continuous attention of executive managers. Towards this end, it is suggested that corporate reputation will have a direct and immediate impact on a firm's subsequent performance, namely; profitability.

Given that a firm's reputation can be a critical source of competitive advantage (Barney, 1991) it is of utmost importance that management proactively manage such a key strategic resource. It is only through vigilance and diligence that management will be able to exploit the full potential of its corporate reputation. However, it is widely recognized that firm reputation is a nebulous and difficult to measure asset (Roberts \& Dowling, 2002; Lippman \& Rumelt, 1982). In spite of its difficult-to-measure nature, it is precisely it ambiguousness that affords it the greatest opportunity for developing a sustainable competitive advantage. As an ambiguous firm asset it is extremely difficult for competing firms to imitate or copy, giving it a longer shelf-life than other identifiable corporate assets.

In addressing the benefits of illusive assets, Roberts \& Dowling (2002) postulate that: "Intangible assets—such as good reputations - are critical because of their potential for value creation, but also because their intangible character makes replication by competing firms considerably more difficult." (p. 1077) So, not only does reputation possess inherent value to a firm by making the firm more valuable, but it also affords the firm a long-term advantage that is causally ambiguous. The inability of competitors to understand a firm's recipe for success limits the overall competitive nature of the industry and gives the possessor of this value resource a "real' advantage in the business arena (Lippman \& Rumelt, 1982).

A variety of different variables are embedded in the concept of corporate reputation. One of these vital variables is crisis management or how a firm responds to a crisis situation. Such crises, in addition to a firm's response to moral and ethical can brand a firm either in a favorable or unfavorable light, depending on their response. An excellent case comparison of this is the different responses to crises as demonstrated by Johnson \& Johnson (Tylenol) and Exxon (Valdez). Johnson \& Johnson has been widely praised for their quick and decisive response, while Exxon has become the poster child for "how not to handle a crisis. The ability to properly handle a crisis can have long-term implications for an organization's overall reputation and image. Research findings suggest that a firm's reputation is intimately linked with firm performance and a firm's long-term survival (Fombrun \& Shanley, 1990).

Researchers have found that a strong and positive reputation can have a favorable impact on a firm through a variety of different ways, including, positively influencing product choices by consumers (Dowling, 1986), preventing and altering the actions of competitors (Caves \& Porter, 1977; Wilson, 1985), and providing an advantageous social standing among competing firms (Shrum \& Wuthnow, 1988). It is argued that any and all of the above mentioned positive impacts will have an overall beneficial impact on a company's profitability, market share, status, customer loyalty, and competitive advantage. All of these factors will have a tendency to insulate and protect a firm from competitive attacks and environmental shocks that will help to insure the success and survival of the company, when compared to other firms will weaker corporate reputations.

As with most variables, corporate reputation has largely been studied in understanding how reputation will impact a firm's financial performance (Fombrun \& Shanley, 1990; McGuire, Sundgren, \& Schneeweis, 1988). Based on past studies in the field of strategy, the general conclusion has been that firms with positive or more favorable reputations will be rewarded with higher rates of profitability than firms will weaker or less favorable reputations (Caves \& Porter, 1977; Fombrun \& Shanley, 1990; McGuire et al., 1988). However, it should be noted that causality has not been the focus of these research studies and therefore, a definitive conclusion cannot be drawn. It is generally expected that if a firm enjoys a more favorable reputation that it will more likely be patronized by consumers than firms that have a poorer or less favorable reputation. If consumers have an overall positive impression of a company then this should lead to that firm being able to generate higher profits.

The most commonly utilized measure of corporate reputation has been the Fortune Reputation Index (FRI). Every year Fortune publishes a listing of the Most Admired Firms, which is a reflection of the firm's overall reputation/image. The FRI has been employed as a proxy for a variety of difficult-to-measure concepts, including: corporate reputation (Fombrun, 1996; Fombrun \& Shanley, 1990), corporate social responsibility 
(Conine \& Madden, 1986; McGuire, et al., 1988), and stakeholder orientation (Chakravarthy, 1986; Preston \& Sapienza, 1990). Due to the popularity of the FRI it has been widely accepted as a valid measure of reputation in the management literature. Detail of the FRI will be outlined in the measurement section of this paper.

However, it should be noted that the FRI has not been universally accepted as the definitive measure of a firm's reputation. Of all the studies that have tested the veracity of the FRI, the most critical attack has been launched by Fryxell \& Wang (1994), who postulated that the FRI did little more than serve as a proxy for financial strength. Their overriding conclusion was that the FRI was comprised of too many financial variables and therefore, was predominately a flection of a firm's financial health and not a valid measure of reputation. Fryxell \& Wang (1994) deemed this overreliance on financial measures in determining the FRI a "financial halo effect". However, it should be highlighted that there was a significant unexplained portion of variance in the study and that such a conclusion might have been premature (Lee \& Hall, 2008). Therefore, is believed by some that the FRI is merely a proxy of a firm's financial performance (i.e. "financial halo") and not a true measure of firm's reputation. Researchers are now left with a puzzling situation. Is the FRI merely another proxy for a firm's financial health? If such an argument is true, then the results of past research studies of reputation, which have largely embraced the FRI as a valid proxy for reputation could be compromised.

Fortunately, Lee \& Hall (2008) conducted a study to specifically address this situation. After controlling for all financial effects it was found that the FRI was still a significant indicator of corporate reputation. Evan after removing the "halo effect" from the study it was determined and concluded that the FRI was a robust and valid representation of a firm's overall corporate reputation and image (Lee \& Hall, 2008). For a complete discussion of the methodology utilized in factoring out and eliminating the halo effect can be found in the studies conducted by Brown \& Perry (1994) and Lee \& Hall (2008).

For the present study it was concluded that the FRI was a proven and valid measure of firm reputation. In addition, the theoretical foundation underlying the FRI will not be debated within the body of the current study. A discussion of the technicalities that lie behind the development and validation of the FRI is better suited for a research study that is focused on methodology and validity. It is our contention that the FRI, as developed by Fortune magazine, more than meets the qualifications to serve as a measure of reputation. Based on present findings it was concluded that the influence of a favorable corporate reputation on a firm's performance is strong and positive, and well worth the attention of senior executives.

The theoretical framework for the study is presented in Figure 1 below.

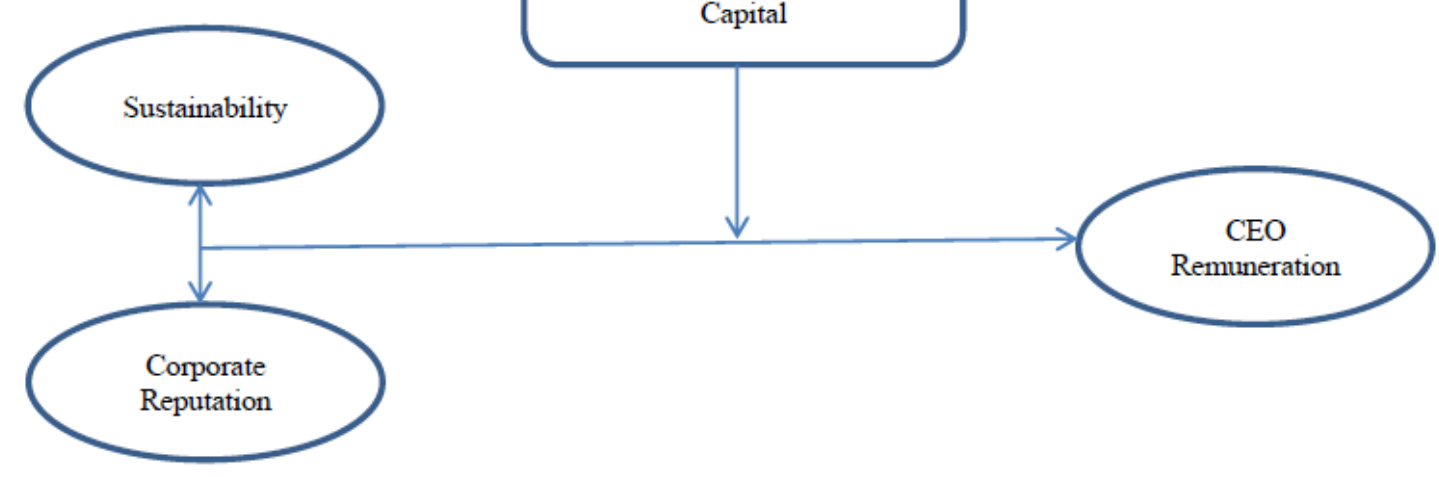

Figure 1. Sustainability-Reputation-Remuneration Framework

It is argued that a CEO remuneration is a complicated a function of a variety of different variables and factors. Two increasingly important factors for CEOs and organizations to consider in this new business environment are sustainability and corporate reputation (Heineman, 2016). Given the current state of affairs in the business world it has become imperative for firms to actively manage and promote their social, environmental, and values-driven strategy to the general public and society at large (Heineman, 2016). The concept of social legitimacy demands that firms, and by association its CEOs, proactively engage with an increasingly turbulent social environment (Hopkins, 2009a). How the firm is viewed by society at large will have a long-term impact 
on a firm's financial performance. Since firm performance has been the central goal of shareholders, and therefore, the primary basis for determining CEO compensation, the relationship between reputation and sustainability, and their influence on a firm's remuneration strategy is of upmost importance (Hall \& Lee, 2011).

The relationship between a firm's reputation (how it is viewed in the business world and society) and its approach to sustainability (its commitment to environmental and ethical issues) will play an increasingly vital role in determining a firm's business strategies in the future. In fact, if current events are any indication of what is coming, a business' very existence will be determined by its social legitimacy. Since the person responsible, and ultimately accountable for a firm's social legitimacy is the CEO, it is critical that compensation be tied directly to social legitimacy. It is widely accepted that executives should be compensated based on their ability to maximize the value/profits of the firm. Since a firm's value/profits will increasingly be determined by its ability to develop, maintain, and sustain a positive firm reputation, and favorable sustainability posture, it will demand that CEOs be compensated based on how well they perform on these new variables.

\section{Hypotheses}

After a thorough review and evaluation of the extant research on the subjects of corporate reputation, sustainability, and executive remuneration, several hypotheses will guide the development of our research study. Each of the hypotheses was derived from a review of the previous research conducted on these topics in the management field. The reasoning for each of the hypotheses was previously developed within the body of the study and was provided earlier, so each of the hypotheses is presented below as a natural conclusion of previous theoretical discussions. Additional support for the hypotheses will not be provided here. There were two primary hypotheses guided the present study.

$\mathrm{H}_{1}$ : $\quad$ CEO remuneration (measured as salary and bonus, long-term compensation, and total compensation) is expected to be positively associated with a firm's reputation after controlling for firm performance and other strategically relevant variables.

$\mathrm{H}_{2}$ : $\quad$ CEO remuneration (measured as salary and bonus, long-term compensation, and total compensation) is expected to be positively associated with corporate sustainability (measured as green score, environmental management, environmental impact, disclosure score) after controlling for corporate reputation, firm performance, and other strategically relevant variables.

\section{Methodology}

\subsection{Sample}

Newsweek's annual publication of the listings of the "Green Rankings" (2010) served as the primary data source for the study. The Green Rankings represent a listing of large, publicly traded firms throughout the world, and their corresponding scores across several sustainability measures. Only firms that were included in the Newsweek 2010 issue of the Green Rankings were included in the study. All data were collected over a five-year period and measured as five-year averages (2010-2014).

Two primary sources, Compact Disclosure and The Directory of Multinationals (Stockton Press), were used for obtaining all the financial data used in the study. CEO compensation data was collected from the Wall Street Journal/Hay Group, and reputation data was operationalized using the Fortune Reputation Index. The final sample included a total of 189 firms. To be included in the final sample, firms had to have complete information for all variables included in the study. It is clearly understood that by employing such stringent standards, that the overall sample size was limited in size. The benefits of complete data for all firms in the sample was deemed to be a more rigorous testing method for the variables being studied and eliminated certain confounding interpretation errors.

Given that the primary variables under study may fluctuate significantly from year-to-year, a five-year average was utilized in the present study to ensure a "truer" assessment a firm's reputation and sustainability status. By adopting a five-year average it can be argued that the measures allow for fluctuations and shifts and are more indicative of the variables true values. A five-year average also allows for environmental and economic shifts that could contaminate a more static measure, such as a one-year measure. Because a firm's strategy is considered a long-term variable, using a five-year average is believed to provide a more accurate measure of a firm's strategy. A five-year average is more likely to present a more dynamic measure of firm strategy than the more static, one-year measures that are frequently used in strategy research (Keats, 1990). 


\subsection{Measurement of Variables}

Several variables were used to help maximize the comparability of the study with past research. By including some of the more commonly used variables in similar studies it is more likely that common specification errors and be avoided. Several key strategic variables were included in the present study to ensure that our examination of CEO remuneration would be comparable with previous studies on the subject.

\subsubsection{Sustainability}

A total of four distinct variables, provided by Newsweek's Green Ranking, were utilized to measure a firm's commitment to sustainability; namely, overall green score, environmental management, environmental impact, and disclosure.

\subsubsection{Overall Green Score}

A composite score of a firm's sustainability strategy is reflected by an overall green score and is total of three different components: environmental impact score, environmental management score, and environmental disclosure score. Each of these measures was combined to create an overall sustainability score (Newsweek's Green Rankings, 2010). Each of the components was weighted as follows to determine the overall green score: $45 \%$ on environmental impact, $45 \%$ on environmental management and 10\% (for additional information and details on how each sustainability variable was calculated is provided by Newsweek.

\subsubsection{Environmental Impact}

In order to evaluate a firm's overall environmental impact Newsweek has developed a composite measure that incorporates more than 700 distinct measures. Some of the areas that are included in the environmental impact measure include greenhouse gases, firm water usage, proper solid waste disposal, and contributing factors to the development of acid rain and smog.

\subsubsection{Environmental Management}

A firm must take an active role in managing their environmental to maximize its impact and accurately report the firm's strategic approach to sustainability. Some of the most common organizational tools that are utilized in sustainability programs included firm/corporate policies, programs, targets, and certifications, all of which form a part of the environmental management index (EMI). EMI is particularly focused on three primary areas of interest, which includes company operations, contractors and suppliers, and products and services. A firm's favorable performance-related history and environmental controversies and incidents were used as an indication of the success of a firm's environmental management systems (Newsweek).

\subsubsection{Disclosure Score}

In addition to having a sustainability strategy it is important to develop a plan for how a firm is going to disclose any environmental issues that might arise due to company mistakes/errors or other negative environmental impacts. A measure, known as the disclosure index is an indication of a firm's willingness to admit and disclose it environmental performance. The disclosure score developed by Newsweek is presented as an assessment of the degree of a firm's willingness to be transparent and accurately report any negative effects its operations might have had on the environment. A firm's willingness to publish and share its environmental disclosures is considered a more honest signal of a firm's commitment to overall sustainability.

\subsubsection{Corporate Reputation}

A firm's reputation was assessed using the commonly accepted Fortune Reputation Index (FRI) developed by Fortune magazine. The FRI utilizes nine different variables to arrive at its reputation index. The nine component parts of the FRI include innovation, social responsibility, people management, use of corporate assets, financial soundness, quality of management, long-term investment, quality of products/services, and global competitiveness. Based on previous studies that have used and vetted the FRI (Hall \& Lee, 2011; Lee \& Hall, 2008), it was concluded that the FRI as calculated by Fortune magazine qualified as valid and reliable proxy of a firm's corporate reputation.

Additionally, it can be argued that the Fortune index has been the most popular measure of corporate reputation in past research studies (Chakravarthy, 1986; Fombrun \& Shanley, 1990; McGuire et al., 1988) and has received recent support in validating the use of the FRI (Hall \& Lee, 2011; Lee \& Hall, 2008) in assessing a firm's corporate reputation, even after controlling for any potential "financial halo" effects.

\subsubsection{Performance Measures}

The most widely used measure of firm performance across business studies has been accounting-based, namely, 
relying on financial data and ratios. Accounting-based measures of performance are the clear choice among strategy scholars and therefore, will be employed in the current study. Of all of the available accounting measures of a firm's financial performance, return on equity (ROE) was selected to ensure the comparability with previous studies (Delios \& Beamish, 1999; Geringer, Beamish, \& da Costa, 1989; Geringer, Tallman, \& Olsen, 2000; Kim, Whang, \& Burgers, 1989; Tallman \& Li, 1996). ROE was measured as follows:

$$
\text { ROE }=\text { Net Profit After-Tax/ Common Stockholder's Equity }
$$

In addition to the traditional accounting-based measure of performance, ROE, Tobin's Q (Amit \& Livnat, 1988) was selected as a more modern and market-based measure. The market-based view of performance, and Tobin's $\mathrm{Q}$ reflect stock market-based views of the firm. In general, market-based measures are considered more long-term measures of a firm's potential performance, while accounting-based measures are mainly viewed as short-term and historical measures of firm performance (Hoskisson, Johnson, \& Moesel, 1994). Both types of financial measures were used to help strengthen the significance of the study.

In addition, Tobin's $\mathrm{Q}$ was selected as a market-based measure due to its popularity among researchers (Lu \& Beamish, 2004; Miller, 2004). In general, Tobin's Q was used as a gauge of financial investors' assessment of a firm's future viability and potential future performance (Amit \& Livnat, 1988). Tobin's Q is also considered to be a more future-oriented measure of firm performance than the historical perspective represented by accounting-based measures. In order to calculate Tobin's $Q$ the following equation was employed.

$$
\begin{aligned}
& \text { Tobin's } \mathrm{Q}=(\text { Market Value of Equity }+ \text { Liquidating Value of Preferred Stock + } \\
& \text { Value of Total Debt)/Total Assets }
\end{aligned}
$$

\subsubsection{Strategic Resource Variables}

It can be argued that CEO remuneration is determined by a variety of different strategic resource variables (Bergh, 1995; Chatterjee \& Wernerfelt, 1991; Lang \& Stulz, 1994; Tallman \& Li, 1996). In order to control for the effects of some key strategic resources, several commonly used variables in strategic management studies were included as control variables, namely, firm size, R \& D intensity (Amit \& Livnat, 1988; Lang \& Stulz, 1994), advertising intensity, and capital intensity (Bergh, 1995; Chatterjee \& Wernerfelt, 1991; Lang \& Stulz, 1994; Tallman \& Li, 1996). Each of these strategic resource variables was calculated as the simple average over the five-year period of 2010-2014.

$$
\begin{gathered}
\text { Firm size }=\text { Ln (sales) } \\
\text { R\&D intensity }=\mathrm{R} \& \mathrm{D} \text { expenditures/total sales }
\end{gathered}
$$

Advertising intensity $=$ advertising expenditures/total sales

$$
\text { Capital intensity }=\text { total assets/total sales }
$$

\subsection{Statistical Methods}

A series of hierarchical regressions were used to examine the relationships among CEO remuneration, corporate reputation, and sustainability. The following multiple regression models were estimated for the sample used in this study.

CEO Remuneration $=$

$$
\begin{array}{cc}
\text { Stage 1: } & \text { ROE } \\
\text { Tobin's Q } \\
\text { Firm size } \\
\text { R\&D intensity } \\
\text { Advertising intensity } \\
\text { Capital intensity }
\end{array}
$$

Stage 2: Corporate reputation

Stage 3: $\quad$ Corporate sustainability 


\section{Results and Analysis}

\subsection{Preliminary Results}

Descriptive statistics and simple correlations suggest that all three measures of CEO compensation were positively and significantly associated with corporate reputation, indicating that CEOs of firms with more positive reputations receive more compensation than CEOs of firms with less positive reputations. Of the different proxies used to measure sustainability, only the green score and the disclosure score were consistently and positively correlated with compensation, while the environmental impact score was related to only long-term compensation. Based on these findings it can be concluded that the model specification was productive in explaining CEO remuneration.

Logic would suggest that firm's that are actively engaged in sustainability programs would also be interested and involved in managing their firm's reputation. The correction be reputation and sustainability supported such an argument. If a firm were cognizant of the impact of their reputation on performance, then firms that had developed sustainability strategies would also likely recognize the damaging effects that ethical, moral, or environmental lapses could have on the firm. Therefore, there should be a close relationship between a firm's reputation and its sustainability program. Firm reputation did not exhibit a strong association a firm's performance, regardless of which measure was employed. The connection between a firm's level of R\&D activity and long-term and total compensation was expectedly positive. Given that Boards of Directors commonly seek to tie long-term compensation to long-term oriented activities to alleviate agency problems, it should not be surprising that such a result was uncovered. $R \& D$ was also positively correlated with reputation and a firm's green score.

Surprisingly, the accounting-based measure of performance, ROE, was not significantly associated with executive remuneration, while Tobin's Q exhibited a negative relationship with compensation. Normally, firm performance would be considered a good indicator of a firm's ability to pay and/or an indicator that the CEO has been successful in managing the firm's resources. Likewise, market-based measures of performance would be expected to correlate with a firm's desire to reward CEOs for favorable stock performance.

\subsection{Results of Regression Analysis}

The empirical models shown previously were estimated using hierarchical regression analysis in an effort to determine the effects of firm reputation and sustainability on CEO compensation. The results of the regression analyses testing the effect of various variables on CEO compensation are presented in Tables 1, 2, 3 and 4 . All statistical models reached significance at the $\mathrm{p}<.001$ level. Overall, the statistical models used in the present study were found to be statistical significant in explaining variances in CEO compensation in the study.

After a thorough examination of the results obtained from the statistical analyses, a number of findings deserve special attention. First, the impact of corporate reputation on CEO remuneration was positive and significant. In all of the models estimated the results indicate that a positive reputation is associated with greater CEO remuneration. Therefore, CEOs are being rewarded for a positive firm reputation and their ability to develop, enhance, and maintain that reputation over time. In general, the more respected the firm is the more the CEO will receive in the way of various forms of compensation. Such results highlight the critical nature of the CEO's impact on a company's image and reputation. Results highlight the importance of a favorable reputation to the firm and CEO and therefore, must be a part of the agenda for upper level business executives. As a key strategic resource, firm reputation can no longer be ignored or marginalized. Executives need to focus on improving and strengthening their firm's reputation in order for the firm and the CEO to reap the benefits that can be afforded by a strong reputation. Developing and maintaining a solid and well-respected reputation will be in the interest of both the firm and the CEO. Regardless of which measure of CEO compensation was employed (salary and bonus, long-term compensation, total compensation), results exhibited a strong and significant relationship across all models. Such a strong, positive relationship lends credence to hypothesis $\mathrm{H}_{1}$. 
Table 1. Results of the Hierarchical Regression Analysis: Overall Green Score

\begin{tabular}{|c|c|c|c|c|c|c|c|c|c|c|c|c|c|c|c|c|c|c|c|c|c|c|c|c|c|c|c|}
\hline \multirow[b]{3}{*}{ (Constant) } & \multirow{2}{*}{\multicolumn{2}{|c|}{ Step 1}} & \multicolumn{4}{|c|}{ Salarly \& Bonus } & & & & \multicolumn{9}{|c|}{ Long-term Compensation } & \multicolumn{9}{|c|}{ Total Compensation } \\
\hline & & & \multicolumn{4}{|c|}{ Step 2} & \multicolumn{3}{|c|}{ Step 3} & \multicolumn{3}{|c|}{ Step 1} & \multicolumn{3}{|c|}{ Step 2} & \multicolumn{3}{|c|}{ Step 3} & \multicolumn{2}{|c|}{ Step 1} & \multicolumn{4}{|c|}{ Step 2} & \multicolumn{3}{|c|}{ Step 3} \\
\hline & 4.665 & (.46) & $* * *$ & 3.562 & $(.49) *$ & *** & 3.490 & $(.50)$ & $* * *$ & 4.370 & $(.53) *$ & $* * *$ & 3.610 & $(.59) *$, & $* * *$ & 3.324 & $(.59) *$ & $* * *$ & 5.065 & $(.45)$ & $* * *$ & 3.892 & $(.48) *$ & **** & 3.693 & $(.48)$ & $* * *$ \\
\hline Return on Equity (ROE) & .002 & $(.00)$ & & .002 & (.00) & & .002 & $(.00)$ & & .002 & $(.00)$ & & .001 & $(.00)$ & & .002 & $(.00)$ & & .001 & $(.00)$ & & .001 & $(.00)$ & & .001 & $(.00)$ & \\
\hline Tobin's Q & -.075 & $(.04)$ & + & -.088 & $(.04) *$ & & -.091 & $(.04) *$ & * & -.068 & $(.05)$ & & -.076 & $(.05)$ & & -.088 & $(.05)+$ & & -.124 & $(.04)$ & *** & -.138 & $(.04) *$ & **** & -.146 & $5(.04)$ & **** \\
\hline Firm Size & 337 & $(.04)$ & $* * *$ & .226 & $(.05) *$ & **** & .208 & $(.05)$ * & $* * *$ & .430 & $(.05) *$ & $* * * *$ & .353 & $(.06) *$ & $* * *$ & .284 & $(.06) *$ & *** & .417 & $(.04)$ & $* * *$ & .299 & $(.05) *$ & $* * *$ & .251 & $(.05)$ & $* * *$ \\
\hline R\&D Intensity & 1.082 & (.73) & & .481 & (.70) & & .414 & (.70) & & 3.299 & $(.84) *$ & **** & 2.885 & $(.84) * 2$ & ***** & 2.622 & $(.83) *$ & ** & 2.768 & $(.72)$ & ***** & 2.129 & $(.68) *$ & *** & 1.947 & $(.68)$ & $* *$ \\
\hline Adverstising Intensity & 3.946 & (1.4) & ** & 2.828 & $(1.3) *$ & & 2.743 & $(1.3) *$ & * & 3.054 & $(1.6)+$ & & 2.284 & (1.6) & & 1.951 & (1.6) & & 3.588 & $(1.4)$ & $* *$ & 2.399 & (1.3) & & 2.168 & $(1.3)$ & + \\
\hline Capital Intensity & .022 & $(.02)$ & & . 024 & $(.01)+$ & + & .024 & $(.01)+$ & + & .008 & $(.02)$ & & .009 & $(.02)$ & & .011 & $(.02)$ & & -.004 & $(.01)$ & & -.002 & $(.01)$ & & -.001 & $(.01)$ & \\
\hline Corporate Reputation & & & & .348 & $(.07) *$ & $* * *$ & .343 & $(.07)$ & **** & & & & .240 & $(.09) *$, & $* *$ & .221 & $(.09) *$ & & & & & .370 & $(.07) *$ & $* * *$ & .357 & $(.07)$ & $* * *$ \\
\hline Overall Green Score & & & & & & & .004 & $(.01)$ & & & & & & & & .016 & $(.01) *$ & & & & & & & & .011 & $(.00)$ & * \\
\hline Model $\mathrm{R}^{2}$ & .3180 & & & .3957 & & & .3979 & & & .3645 & & & .3903 & & & .4141 & & & .4303 & & & .5051 & & & .5193 & & \\
\hline Adjusted $\mathrm{R}^{2}$ & .2956 & & & .3723 & & & .3712 & & & .3436 & & & .3667 & & & .3884 & & & .4115 & & & .4860 & & & .4980 & & \\
\hline Change in $\mathrm{R}^{2}$ & & & & .0780 & & & .0200 & & & & & & .0261 & & & .0240 & & & & & & .0750 & & & .0140 & & \\
\hline F-value & 14.15 & $* * *$ & & 16.93 & $* * *$ & & $14.87 *$ & *** & & 17.41 & $* * *$ & & 5.11 & $* * *$ & & 15.92 & $* * *$ & & 22.91 & $* * *$ & & 26.39 , & $* * *$ & & 24.31 & $* * *$ & \\
\hline F-value for Change in $R^{2}$ & & & & 23.25 , & $* * *$ & & 0.67 & & & & & & 7.649 & $* *$ & & 7.40 & $* *$ & & & & & 27.36 , & $* * *$ & & 5.33 & $*$ & \\
\hline & & & & & & & & & & & & & & & & & & & & & & & & & & & \\
\hline \multicolumn{28}{|c|}{${ }^{a}$, $n=189$ Unstandardized regression coefficients are shown and Standard errors are in parenttheses } \\
\hline Significance level: $+\mathrm{P}<0$ & $10 ; * \mathrm{~F}$ & $<0.05$ & ;* $\mathrm{P}$ & $P<0.01$ & 1 ; *** & $P$ & 0.001 & & & & & & & & & & & & & & & & & & & & \\
\hline & & & & & & & & & & & & & & & & & & & & & & & & & & & \\
\hline
\end{tabular}

Table 2. Results of the Hierarchical Regression Analysis: Environmental Management

\begin{tabular}{|c|c|c|c|c|c|c|c|c|c|c|c|c|c|c|c|c|c|c|c|c|c|c|c|c|c|c|c|}
\hline & & & \multicolumn{4}{|c|}{ Salarly \& Bonus } & & & & \multicolumn{8}{|c|}{ Long-term Compensation } & & \multicolumn{6}{|c|}{ Total Compensation } & & & \\
\hline & \multicolumn{2}{|c|}{ Step 1} & & \multicolumn{3}{|c|}{ Step 2} & \multicolumn{3}{|c|}{ Step 3} & \multicolumn{3}{|c|}{ Step 1} & \multicolumn{3}{|c|}{ Step 2} & \multicolumn{2}{|c|}{ Step 3} & \multicolumn{3}{|c|}{ Step 1} & \multicolumn{3}{|c|}{ Step 2} & \multicolumn{3}{|c|}{ Step 3} & \\
\hline (Constant) & 4.665 & (.46) & *** & 3.562 & (.49) & $* * *$ & 3.624 & $(.49)$ & $* * *$ & 4.370 & (.53) & $* * *$ & 3.610 & $(.59)$ & $* * *$ & 3.598 & $(.59)$ & $* * *$ & 5.065 & (.45) & $* * *$ & 3.892 & $(.48)$ & $* * *$ & * 3.961 & (.48) & ) $* * *$ \\
\hline Return on Equity (ROE) & .002 & $(.00)$ & & .002 & $(.00)$ & & .002 & $(.00)$ & & .002 & $(.00)$ & & .001 & $(.00)$ & & .001 & $(.00)$ & & .001 & $(.00)$ & & .001 & $(.00)$ & & .001 & $(.00)$ & \\
\hline Tobin's Q & -.075 & $(.04)$ & + & -.088 & $(.04)$ & * & -.091 & $(.04)$ & * & -.068 & $(.05)$ & *** & -.076 & $(.05)$ & & -.076 & $(.05)$ & & -.124 & $(.04)$ & ** & -.138 & $(.04)$ & ) $* * *$ & - -.141 & $(.04)$ & ) *** \\
\hline Firm Size & .337 & $(.04)$ & *** & .226 & $(.05)$ & $* * *$ & .235 & $(.05)$ & $* * *$ & .430 & $(.05)$ & $* * *$ & .353 & $(.06)$ & $* * *$ & .351 & $(.06)$ & $* * *$ & .417 & $(.04)$ & $* * *$ & .299 & $(.05)$ & ) $* * *$ & * .309 & $(.05)$ & ) $* * *$ \\
\hline R\&D Intensity & 1.082 & $(.73)$ & & 481 & (.70) & & .612 & $(.70)$ & & 3.299 & $(.84)$ & + & 2.885 & $(.84)$ & **** & 2.859 & (.85) & $* * *$ & 2.768 & $(.72)$ & $* * *$ & 2.129 & $(.68)$ & )** & 2.276 & $(.68)$ & ) *** \\
\hline Adverstising Intensity & (3.9) & (1.4) & $* *$ & (2.8) & (1.3) & * & $(3.1)$ & $(1.3)$ & * & (3.1) & (1.6) & & (2.3) & (1.6) & & (2.2) & (1.6) & & (3.6) & $(1.4)$ & $* *$ & (2.4) & $(1.3)$ & + & (2.7) & (1.3) & ) * \\
\hline Capital Intensity & .022 & $(.02)$ & & .024 & $(.01)$ & + & .024 & $(.01)$ & & .008 & $(.02)$ & & .009 & $(.02)$ & & .009 & $(.02)$ & & -.004 & $(.01)$ & & -.002 & $(.01)$ & & -.001 & (.01) & \\
\hline Corporate Reputation & & & & .348 & $(.07)$ & *** & .356 & $(.07)$ & $* * *$ & & & & .240 & $(.09)$ & $* *$ & .238 & $(.09)$ & $* * *$ & & & & .370 & $(.07)$ & $* * *$ & .379 & (.07) & )** \\
\hline Environmental Mgmt & & & & & & & -.004 & $(.00)$ & + & & & & & & & .001 & $(.00)$ & & & & & & & & -.005 & $(.00)$ & ) \\
\hline Model $\mathrm{R}^{2}$ & .3180 & & & .3957 & & & .4061 & & & .3645 & & & .3903 & & & .3906 & & & .4303 & & & .5051 & & & .5161 & & \\
\hline Adjusted $\mathrm{R}^{2}$ & .2956 & & & .3723 & & & .3797 & & & .3436 & & & .3667 & & & .3635 & & & .4115 & & & .4860 & & & .4946 & & \\
\hline Change in $\mathrm{R}^{2}$ & & & & .0776 & & & .0104 & & & & & & .0260 & & & .0000 & & & & & & .0750 & & & .0112 & & \\
\hline F-value & 14.15 & $* * *$ & & 16.93 & $* * *$ & & 15.38 & $* * *$ & & 17.40 & $* * *$ & & 16.55 & *** & & 14.42 & $* * *$ & & $22.91 *$ & $* * *$ & & 26.39 & $* * *$ & & 24.00 & $* * *$ & \\
\hline F-value for Change in $\mathrm{R}^{2}$ & & & & 23.25 & $* * *$ & & 3.14 & & & & & & 7.649 & $* *$ & & 0.08 & & & & & & 27.36 & $* * *$ & & 4.09 & $*$ & \\
\hline & & & & & & & & & & & & & & & & & & & & & & & & & & & \\
\hline \multicolumn{28}{|c|}{${ }^{a}, n=189$ Unstandardized regression coefficients are shown and Standard errors are in parenttheses } \\
\hline Significance level: $+\mathrm{P}<$ & $10 ; * P$ & $<0.05$ & & $P<0.01$ & $1 ;{ }^{* *}$ & & 0.001 & & & & & & & & & & & & & & & & & & & & \\
\hline & & & & & & & & & & & & & & & & & & & & & & & & & & & \\
\hline
\end{tabular}

Table 3. Results of the Hierarchical Regression Analysis: Environmental Impact

\begin{tabular}{|c|c|c|c|c|c|c|c|c|c|c|c|c|c|c|c|c|c|c|c|c|c|c|c|c|c|c|}
\hline & & & \multicolumn{4}{|c|}{ Salarly \& Bonus } & & & & \multicolumn{9}{|c|}{ Long-term Compensation } & \multicolumn{6}{|c|}{ Total Compensation } & & \\
\hline & \multicolumn{2}{|c|}{ Step 1} & & \multicolumn{3}{|c|}{ Step 2} & \multicolumn{2}{|c|}{ Step 3} & \multicolumn{3}{|c|}{ Step 1} & & \multicolumn{3}{|c|}{ Step 2} & \multicolumn{2}{|c|}{ Step 3} & \multicolumn{3}{|c|}{ Step 1} & \multicolumn{4}{|c|}{ Step 2} & \multicolumn{2}{|c|}{ Step 3} \\
\hline (Constant) & 4.665 & $(.46)$ & *** & 3.562 & $(.49)$ & **** & 3.542 & $(.50)$ & $* * *$ & 4.370 & (.53) & $* * *$ & 3.610 & (.59) & $* * *$ & 3.560 & $(.60)$ & **** & 5.065 & $(.45)$ & *** & 3.892 & $(.48)$ & $* * *$ & 3.870 & (.49) \\
\hline Return on Equity (ROE) & .002 & $(.00)$ & & .002 & $(.00)$ & & .002 & $(.00)$ & & .002 & $(.00)$ & & .001 & $(.00)$ & & .001 & $(.00)$ & & .001 & $(.00)$ & & .001 & $(.00)$ & & .001 & $(.00)$ \\
\hline Tobin's Q & -.075 & $(.04)$ & + & -.088 & $(.04)$ & * & -.089 & $(.04)$ & * & -.068 & (.05) & & -.076 & $(.05)$ & & -.078 & $(.05)$ & & -.124 & $(.04)$ & ** & -.138 & $(.04)$ & $* * *$ & -.139 & $(.04)$ \\
\hline Firm Size & .337 & $(.04)$ & $* * *$ & .226 & $(.05)$ & *** & .224 & (.05) & $* * *$ & .430 & (.05) & $* * *$ & .353 & (.06) & $* * *$ & .348 & $(.06)$ & $* * *$ & .417 & $(.04)$ & *** & .299 & $(.05)$ & $* * *$ & .297 & $(.05)$ \\
\hline R\&D Intensity & 1.082 & (.73) & & .481 & $(.70)$ & & .457 & (.71) & & 3.299 & (.84) & $* * *$ & 2.885 & $(.84)$ & $* * *$ & 2.826 & $(.85)$ & $* * *$ & 2.768 & $(.72)$ & *** & 2.129 & $(.68)$ & $* *$ & 2.103 & (.69) \\
\hline Adverstising Intensity & 3.946 & (1.4) & ** & 2.828 & $(1.3)$ & * & 2.832 & (1.3) & * & 3.054 & (1.6) & + & 2.284 & (1.6) & & 2.293 & (1.6) & & 3.588 & $(1.4)$ & ** & 2.399 & (1.3) & + & 2.403 & (1.3) \\
\hline Capital Intensity & .022 & $(.02)$ & & .024 & $(.01)$ & + & .024 & $(.01)$ & & .008 & $(.02)$ & & .009 & $(.02)$ & & .008 & $(.02)$ & & -.004 & $(.01)$ & & -.002 & (.01) & & -.002 & $(.01)$ \\
\hline Corporate Reputation & & & & .348 & $(.07)$ & *** & .351 & (.07) & $* * *$ & & & & .240 & $(.09)$ & ** & 247 & (.09) & $* *$ & & & & .370 & $(.07)$ & $* * *$ & .374 & $(.07)$ \\
\hline Environmental Impact & & & & & & & .000 & $(.00)$ & & & & & & & & .001 & $(.00)$ & & & & & & & & .001 & $(.00)$ \\
\hline Model $\mathrm{R}^{2}$ & 3180 & & & .3957 & & & 3959 & & & 3645 & & & .3903 & & & .3643 & & & 4303 & & & .5051 & & & .5054 & \\
\hline Adjusted $\mathrm{R}^{2}$ & .2956 & & & .3723 & & & .3691 & & & .3436 & & & .3667 & & & .3643 & & & .4115 & & & .4860 & & & .4834 & \\
\hline Change in $\mathrm{R}^{2}$ & & & & .0776 & & & .0002 & & & & & & .0258 & & & .0010 & & & & & & .0748 & & & .0002 & \\
\hline F-value & 14.147 & $* * *$ & & 6.931 & $* * *$ & & 4.748 & $* * *$ & & 17.401 & *** & & 16.553 & *** & & 14.464 & $* * *$ & & 22.911 & *** & & 26.392 & $* * *$ & & 22.988 & $* * *$ \\
\hline F-value for Change in $\mathrm{R}^{2}$ & & & & 23.25 & $* * *$ & & .070 & & & & & & 7.649 & $* *$ & & .294 & & & & & & 27.364 & $* * *$ & & .089 & \\
\hline \multirow{2}{*}{\multicolumn{27}{|c|}{ a, $n=189$ Unstandardized regression coefficients are shown and Standard errors are in parenttheses }} \\
\hline & & & & & & & & & & & & & & & & & & & & & & & & & & \\
\hline Significance level: $+\mathrm{P}<\mathrm{C}$ & $.10 ;{ }^{*} \mathrm{P}$ & $<0.05$; & & $P<0.01$ & $1 ;$; $^{*}$ & Kc & 0.001 & & & & & & & & & & & & & & & & & & & \\
\hline & & & & & & & & & & & & & & & & & & & & & & & & & & \\
\hline
\end{tabular}


Table 4. Results of the Hierarchical Regression Analysis: Disclosure Score

\begin{tabular}{|c|c|c|c|c|c|c|c|c|c|c|c|c|c|c|c|c|c|c|c|c|c|c|c|c|c|c|c|}
\hline & & & \multicolumn{4}{|c|}{ Salarly \& Bonus } & & & & \multicolumn{9}{|c|}{ Long-term Compensation } & \multicolumn{8}{|c|}{ Total Compensation } & \\
\hline & \multicolumn{2}{|c|}{ Step 1} & & \multicolumn{3}{|c|}{ Step 2} & \multicolumn{2}{|c|}{ Step 3} & \multicolumn{4}{|c|}{ Step 1} & \multicolumn{3}{|c|}{ Step 2} & \multicolumn{2}{|c|}{ Step 3} & & \multicolumn{2}{|c|}{ Step 1} & \multicolumn{3}{|c|}{ Step 2} & \multicolumn{3}{|c|}{ Step 3} & \\
\hline (Constant) & 4.665 & $(.46)$ & $* * *$ & 3.562 & (.49) & $* * *$ & 3.692 & $(.50)$ & $* * *$ & 4.370 & $(.53)$ & **** & 3.610 & (.59) & $* * *$ & 3.862 & $(.59)$ & *** & 5.065 & $(.45)$ & *** & 3.892 & $2(.48)$ & )** & * 4.068 & (.49) & *** \\
\hline Return on Equity (ROE) & .002 & $(.00)$ & & .002 & $(.00)$ & & .002 & $(.00)$ & & .002 & $(.00)$ & & .001 & $(.00)$ & & .001 & $(.00)$ & & .001 & $(.00)$ & & .001 & $(.00)$ & & .001 & $(.00)$ & \\
\hline Tobin's Q & -.075 & $(.04)$ & + & -.088 & $(.04)$ & * & -.089 & $(.04)$ & * & -.068 & $(.05)$ & & -.076 & $(.05)$ & & -.078 & $(.05)$ & & -.124 & $(.04)$ & ** & -.138 & $3(.04)$ & *** & $*-.139$ & $(.04)$ & *** \\
\hline Firm Size & .337 & $(.04)$ & $* * *$ & .226 & $(.05)$ & *** & .205 & $(.05)$ & *** & .430 & $(.05)$ & *** & .353 & $(.06)$ & $* * *$ & .311 & (.06) & *** & .417 & $(.04)$ & *** & .299 & $(.05)$ & ) $* * *$ & $* .270$ & $(.05)$ & *** \\
\hline R\&D Intensity & 1.082 & $(.73)$ & & .481 & $(.70)$ & & 457 & $(.70)$ & & 3.299 & $(.84)$ & *** & 2.885 & $(.84)$ & $* * *$ & 2.838 & $(.83)$ & **** & 2.768 & $(.72)$ & *** & 2.129 & (.68) & ) $* *$ & 2.096 & (.68) & ** \\
\hline Adverstising Intensity & 3.946 & (1.4) & $* *$ & 2.828 & (1.3) & * & 2.789 & (1.3) & * & 3.054 & (1.6) & + & 2.284 & (1.6) & & 2.207 & (1.6) & & 3.588 & $(1.4)$ & ** & 2.399 & $(1.3)$ & + & 2.346 & (1.3) & + \\
\hline Capital Intensity & .022 & $(.02)$ & & .024 & $(.01)$ & + & .024 & $(.01)$ & + & .008 & $(.02)$ & & .009 & $(.02)$ & & .009 & $(.02)$ & & -.004 & $(.01)$ & & -.002 & $2(.01)$ & & -.002 & $(.01)$ & \\
\hline Corporate Reputation & & & & .348 & $(.07)$ & $* * *$ & .335 & $(.07)$ & $* * *$ & & & & .240 & $(.09)$ & ** & .214 & $(.09)$ & $* *$ & & & & .370 & $(.07)$ & ) $* * *$ & * .352 & $(.07)$ & *** \\
\hline Disclosure Score & & & & & & & .004 & $(.00)$ & & & & & & & & .008 & $(.00)$ & $*$ & & & & & & & .005 & $(.00)$ & * \\
\hline Model $\mathrm{R}^{2}$ & .3180 & & & .3957 & & & .4023 & & & .3645 & & & .3667 & & & .3815 & & & .4303 & & & .5051 & & & .5155 & & \\
\hline Adjusted $\mathrm{R}^{2}$ & .2956 & & & .3723 & & & .3757 & & & .3436 & & & .3667 & & & .3815 & & & .4115 & & & .4860 & & & .4940 & & \\
\hline Change in $R^{2}$ & & & & .0776 & & & .0066 & & & & & & 7.649 & & & 5.324 & & & & & & .0748 & & & .0104 & & \\
\hline F-value & 14.147 & $* * *$ & & 16.931 & $* * *$ & & 15.143 & $* * *$ & & 17.401 & $* * *$ & & 16.553 & *** & & 15.495 & *** & & 22.911 & *** & & 26.392 & *** & & 23.938 & *** & \\
\hline F-value for Change in $R^{2}$ & & & & 23.257 & $* * *$ & & 1.982 & & & & & & 7.649 & $* *$ & & 5.323 & $*$ & & & & & 27.364 & $* * *$ & & 4.852 & $*$ & \\
\hline & & & & & & & & & & & & & & & & & & & & & & & & & & & \\
\hline \multicolumn{28}{|c|}{${ }^{a}$ n $=189$ Unstandardized regression coefficients are shown and Standard errors are in parenttheses } \\
\hline Significance level: $+\mathrm{P}<$ & $0.10 ; *$ & $<0.0$ & 5; & $* P<0$. & $1 ; * * *$ & $* \mathrm{P}<$ & $<0.001$ & & & & & & & & & & & & & & & & & & & & \\
\hline & & & & & & & & & & & & & & & & & & & & & & & & & & & \\
\hline
\end{tabular}

Second, the only measures of sustainability to show significant relationships with CEO compensation were the overall 'green' score and the disclosure score. It is interesting that the two measures of sustainability which are most discernible and readily identifiable by the public were the ones that were positively related with compensation. Both of these variables are directly related to the FRI and may be factored into evaluation of a firm's reputation. Environmental impact and environmental management are much more difficult to assess publicly and may explain why neither of these variables were significant in explaining a CEO's compensation package.

Third, R\&D and firm size were found to have a positive impact on CEP remuneration. It should be noted that the strength of the relationship between performance and firm size was consistently strong and positive across all models. Advertising intensity was also positively related to CEO pay, although the results were not unanimous across all measures of CEO pay. The size of a firm and its requisite stature and complexity may demand that they offer more lucrative compensation packages in order to attract highly experienced CEOs. Likewise, R\&D and advertising intensity are likely to reflect a firm's desire to promote a favorable image of one self (advertising) and reflect a firm's progressive persona of being on the cutting edge of technology and frequent product innovations $(R \& D)$. Image management would be expected to be closely tied to a firm's ability to promote and advertise their products through advertising.

\section{Conclusion}

Findings obtained from the statistical analyses of the present study show a statistically positive and robust

correlation between CEO remuneration, and a healthy and favorable firm reputation. The relationship between remuneration and reputation was found to be positive and consistent across all measures of remuneration, and suggests a very robust foundation upon which to build compensation strategies. The linkage between compensation and reputation uncovered in the present study is even more impressive when it is recognized that these findings persevered despite controlling for other key strategic resources that have been shown to have meaningful impacts on a CEO's total remuneration package. Firm reputation, with all of its complexities and nuances, has proven itself to be a very valuable company resource, a resource which is intimately tied to CEO remuneration and firm profitability. CEOs that appreciate and understand this relationship will be able to craft business strategies that will both benefit the firm and the CEO. Aligning CEO compensation and firm performance has been a long-time tool used by Boards of Directors to help improve profitability and stock price. A well-planned and proactive strategy designed to highlight the importance of firm reputation is likely to be beneficial for both the company and the CEO, if a favorable and positive firm reputation can be developed and maintained for the company.

In addition, a firm's sustainability program will likely have an impact on the compensation of CEOs, especially when it comes to measures that are more publicly available and conspicuous to consumers. Research suggests that sustainability will continue to have a more significant impact on a firm's reputation, especially given the social legitimacy movement that has dominated the business press. No longer can firms ignore or pacify society by merely donating resources to popular causes. Firms are now expected to take leadership roles for social change and the betterment of society at large. The connection between a firm's sustainability program and its 
values must be intimately connected. Therefore, sustainability is expected to play a vital role in determining a business's reputation. It is imperative that CEOs understand this relationship and the power of social legitimacy to be able to maximize their own compensation and the profits of the firm they represent.

As is true with all empirical studies, there are limitations of the present study that may have biased the results in an unpredictable way. First, the selection of one five-year period may have inadvertently introduced idiosyncratic biases that could not be predicted. Results from the period studied may not have uncovered sustainability effects, due to the long-term nature of the variable. Incorporating a more extensive longitudinal database may have uncovered other important findings with regard to the effects of corporate reputation and sustainability on CEO compensation.

Second, it should be noted, that corporate reputation and sustainability are complex and multifaceted variables that can be defined in a variety of ways and from a variety of different perspectives. Due to their sophisticated and complicated natures, more creative and rigorous statistical methods may be necessary to thoroughly understand reputation and sustainability. In addition, it was not feasible to include all control variables that may have an impact on the variables being studied. Results of any study will be impacted by errors of specification. Depending on which control variables are included, results may vary. It is also recognized that controlling for industry effects, along with firm structure, would have likely strengthened the present study and provided a more realistic assessment of the reputation-sustainability-remuneration relationship.

\section{References}

Amit, R., \& Livnat, J. (1988). Diversification and the risk-return tradeoff. Academy of Management Journal, 31, 154-165. https://doi.org/10.5465/256502

Barney, J. (1991). Firm resources and sustained competitive advantage. Journal of Management, 17, 99-120. https://doi.org/10.1177/014920639101700108

Bergh, D. D. (1995). Size and relatedness of units sold: An agency theory and resource-based perspective. Strategic Management Journal, 16, 221-239. https://doi.org/10.1002/smj.4250160306

Brown B., \& Perry, S. (1994). Removing the financial performance halo from Fortune's "Most Admired" companies. Academy of Management Journal, 37, 1347-1359. https://doi.org/10.2307/256676

Caves, R. E., \& Porter, M. E. (1977). From entry barriers to mobility barriers. Quarterly Journal of Economics, 91, 421-434. https://doi.org/10.2307/1885416

Chakravarthy, B. (1986). Measuring strategic performance. Strategic Management Journal, 7, 437-458. https://doi.org/10.1002/smj.4250070505

Chatterjee, S., \& Wernerfelt, B. (1991). The link between resources and type of diversification: Theory and evidence. Strategic Management Journal, 12, 33-48. https://doi.org/10.1002/smj.4250120104

Conine, T. F., \& Madden, G. P. (1986). Corporate social responsibility and investment value. In W. D. Guth (Ed.), Handbook of Business Strategy1986/1987 Yearbook. Boston: Warren, Gorham \& Lamont.

Delios, A., \& Beamish, P. W. (1999). Geographic scope, product diversification, and the corporate performance of Japanese firms. Strategic Management Journal, 20, 711-727. https://doi.org/10.1002/(SICI)1097-0266(199908)20:8<711::AID-SMJ41>3.0.CO;2-8

Dowling, G. R. (1986). Managing your corporate images. Industrial Marketing Management, 15, 109-115. https://doi.org/10.1016/0019-8501(86)90051-9

Fombrun, C. (1996). Reputation: Realizing value from the corporate image. Boston: Harvard Business School Press.

Fombrun, C., \& Shanley, M. (1990). What's in a name? Reputation building and corporate strategy. Academy of Management Journal, 33, 233-258. https://doi.org/10.5465/256324

Fryxell, G. E., \& Wang, J. (1994). The Fortune corporate 'Reputation' index: Reputation for what? Journal of Management, 20, 1-14. https://doi.org/10.1177/014920639402000101

Geringer, M. J., Beamish, B. W., \& daCosta R. C. (1989). Diversification strategy and internationalization: Implications for MNE performance. Strategic Management Journal, 10, 109-119. https://doi.org/10.1002/smj.4250100202

Geringer, M. J., Tallman, S., \& Olsen, D. M. (2000). Product and international diversification among Japanese multinational firms. Strategic Management Journal, 21, 51-80. 
https://doi.org/10.1002/(SICI)1097-0266(200001)21:1<51::AID-SMJ77>3.0.CO;2-K

Hall, J. E. H., \& Lee, J. (2011). A CEO's Most Important Strategic Asset: Assessing Corporate Reputation. International Journal of Business and Management Research, 1(3), 1-19.

Hall, Jr., E. H., Lee, J., \& Whang, K. S. (2011). An International Study of Corporate Reputation, Diversification, and Performance. International Journal of Economics and Management, 1(3), 1-23.

Heineman, J. B.W. (2016). The "Business in Society" Imperative for CEOs, Harvard Business Review, Dec. 20, 2016.

Hopkins, M. (2009a). Sustainability and competitive advantage. Sloan Management Review, 51(1), 19-20.

Hopkins, M. (2009b). What executives don't get about sustainability, Sloan Management Review, 51(1), 35-40.

Hoskisson, R. E., Johnson, R. A., \& Moesel, D. D. (1994). Corporate divestiture intensity in restructuring firms-Effects of governance, strategy, and performance. Academy of Management Journal, 37, 1207-1251. https://doi.org/10.2307/256671

Keats, B. W. (1990). Diversification and business economic performance revisited: Issues of measurement and causality. Journal of Management, 16, 61-72. https://doi.org/10.1177/014920639001600105

Kim, C. W., Hwang, P., \& Burgers, W. P. (1989). Global diversification strategy and corporate profit performance. Strategic Management Journal, 10, 45-57. https://doi.org/10.1002/smj.4250100105

Kiron, D., Kruschwitz, N., Haanaes, K., \& Von Streng Velken, I. (2009). Sustainability nears a tipping point. Sloan Management Review, 51(1), 69-74.

Klein, B., \& Leffler, K. (1981). The role of market forces in assuring contractual performance. Journal of Political Economy, 89, 615-641. https://doi.org/10.1086/260996

Kochan, T. A. (2015). Social Legitimacy of the HRM Profession: A US Perspective. In P.Boxall, J. Purcell, \& P. M. Wright (Eds.), The Oxford Handbook of Human Resources Management, (www.oxfordhandbooks.com), Oxford University Press.

Lang, L. H. P., \& Stulz, R. M. (1994). Tobin's q, corporate diversification, and firm performance. Journal of Political Economy, 102(6), 1248-1280. https://doi.org/10.1086/261970

Lee, J., \& Hall, J. E. H. (2008). An Empirical Investigation of the 'Halo' Effect of Financial Performance on the Relationship between Corporate Reputation and CEO Compensation. American Journal of Business Research, 1(1), 93-110.

Lippman, S. A., \& Rumelt, R. P. (1982). Uncertain Imitablity: An analysis of interfirm differences in efficiency under competition. Bell Journal of Economics, I3, 418-438. https://doi.org/10.2307/3003464

Lu, J. W., \& Beamish, P. W. (2004). International diversification and firm performance: The S-curve hypothesis, Academy of Management Journal, 47(4), 598-609. https://doi.org/10.2307/20159604

McGuire, J., Sundgren, A., \& Schneeweis, T. (1988). Corporate social responsibility and firm financial performance. Academy of Management Journal, 31, 854-872. https://doi.org/10.2307/256342

Milgrom, P., \& Roberts, J. (1986). Price and advertising signals of product quality. Journal of Political Economy, 94, 796-821. https://doi.org/10.1086/261408

Miller, D. J. (2004). Firms' Technological Resources and the Performance Effects of Diversification: A Longitudinal Study. Strategic Management Journal, 25, 1097-1119. https://doi.org/10.1002/smj.411

Porter, M. E. (1990). The competitive advantage of nations. Harvard Business review, March-April, 73-93. https://doi.org/10.1007/978-1-349-11336-1

Preston, L. E., \& Sapienza, H. T. (1990). Stakeholder management and corporate performance. Journal of Behavioral Economics, 19, 361-375. https://doi.org/10.1016/0090-5720(90)90023-Z

Roberts, R. W., \& Dowling, G. R. (2002). Corporate reputation and sustained superior financial performance, Strategic Management Journal, 23, 1077-1093. https://doi.org/10.1002/smj.274

Shrum, W., \& Wuthnow, R. (1988). Reputational status of organizations in technical systems. American Journal of Sociology, 93, 882-912. https://doi.org/10.1086/228828

Suriyankietkaew, S., \& Petison, P. (2020). A Retrospective and Foresight: Bibliometric Review of International Research on Strategic Management for Sustainability, 1991-2019. Sustainability, 12(1), 91. https://doi.org/10.3390/su12010091 
Tallman, S., \& Li, J. (1996). Effects of international diversity and product diversity on the performance of multinational firms. Academy of Management Journal, 39, 179-196. https://doi.org/10.2307/256635

Wilson, R. (1985). Reputations in games and markets. In A. E. Roth (Ed.), Game theoretic models of bargaining, (pp. 65-84). New York: Cambridge University Press. https://doi.org/10.1017/CBO9780511528309.004

\section{Copyrights}

Copyright for this article is retained by the author(s), with first publication rights granted to the journal.

This is an open-access article distributed under the terms and conditions of the Creative Commons Attribution license (http://creativecommons.org/licenses/by/4.0/). 